\title{
The interaction among insulin resistance, liver fibrosis and early virological response in Egyptian patients with chronic hepatitis $\mathrm{C}$
}

\author{
Dina H Ziada MD¹, Sherif El Saadany MD ${ }^{1}$, Mohamed Enaba MD², \\ Medhat Ghazy MD², Azza Hasan MD³
}

DH Ziada, S El Saadany, M Enaba, M Ghazy, A Hasan. The interaction among insulin resistance, liver fibrosis and early virological response in Egyptian patients with chronic hepatitis $\mathrm{C}$. Can J Gastroenterol 2012;26(6):325-329

BACKGROUND: Hepatitis C virus (HCV) infection may induce insulin resistance (IR) irrespective of the severity of liver disease, and there is evidence of a central role for IR in failure to achieve sustained virological response (SVR) in HCV patients.

OBJECTIVE: To assess IR as a predictor of the severity of hepatic fibrosis in Egyptian HCV patients, and its effect on early viral kinetics and virological response to HCV therapy.

METHODS: A total of 140 chronic HCV patients were divided into two groups according to the homeostasis model assessment-IR (HOMA-IR). Group 1 consisted of 48 chronic HCV patients with HOMA-IR $\geq 2$, and group 2 consisted of 92 chronic HVC patients without IR (HOMA IR <2). All patients were treated with combination therapy (pegylated interferon-alpha 2a plus ribavirin) for 48 weeks and studied for viral kinetics throughout the period of therapy.

RESULTS: The study revealed that older age, higher body mass index and HOMA-IR $\geq 2$ were significantly associated with advanced fibrosis. Rapid virological response, complete early virological response and SVR were significantly lower in the IR-HCV group compared with the non-IR-HCV group. Univariate and multivariate analyses revealed that older age, fibrosis $(\mathrm{F} \geq 3)$, high viral load $(>600,000 \mathrm{IU} / \mathrm{mL})$ and HOMA-IR $\geq 2$ were significantly associated with a lack of viral kinetics as well as SVR. However, HOMA-IR $\geq 2$ was the main independent variable associated with lack of SVR. On the other hand, body mass index, plasma insulin level and HOMA-IR decreased significantly compared with starting levels in patients who achieved SVR. This suggests a cause and effect relationship between HCV infection and IR.

CONCLUSION: IR in chronic HCV patients is associated with progressive fibrosis and slow viral kinetics, and could be a predictor for lack of rapid and early virological response. Therefore, HOMA-IR levels should be measured and improved before starting antiviral treatment.

Key Words: HCV; HCV therapy response; HOMA-IR; Insulin resistance; Liver fibrosis

\author{
L'interaction entre l'insulinorésistance, la fibrose \\ hépatique et la réponse virologique précoce chez \\ des patients égyptiens ayant une hépatite $\mathrm{C}$ \\ chronique
}

HISTORIQUE : L'infection par le virus de l'hépatite C (VHC) peut être induite par l'insulinorésistance (IR), quelle que soit la gravité de la maladie hépatique, et des données probantes laissent supposer le rôle central de l'IR dans l'incapacité à obtenir une réponse virologique soutenue (RVS) chez les patients atteints du VHC.

OBJECTIF : Évaluer l'IR comme prédicteur de la gravité de la fibrose hépatique chez des patients égyptiens atteints du VHC, ainsi que son effet sur la cinétique virale précoce et la réponse virologique à la thérapie du VHC.

MÉTHODOLOGIE : Au total, 140 patients atteints du VHC chronique ont été répartis en deux groupes d'après l'évaluation du modèle d'homéostase-IR (ÉMHO-IR). Le groupe 1 se composait de 48 patients atteints du VHC chronique dont l'ÉMHO-IR était supérieure à 2, et le groupe 2, de 92 patients atteints du VHC chronique sans IR (ÉMHO-IR inférieure à 2). Tous les patients ont été traités par polythérapie (interféron-gamma 2a pégylé associé à de la ribavirine) pendant 48 semaines et ont fait l'objet d'une étude de cinétique virale tout au long de la période de thérapie.

RÉSULTATS : L'étude a révélé qu'un âge plus avancé, un indice de masse corporelle plus élevé et une ÉMHO-IR supérieure à 2 s'associaient considérablement à une fibrose avancée. La réponse virologique rapide, la réponse virologique précoce complète et la RVS étaient considérablement plus faibles dans le groupe d'IR-VHC que dans celui sans IR. Les analyses univariée et multivariée ont révélé qu'un âge plus avancé, une fibrose $\mathrm{F} \geq 3$, une charge virale élevée (supérieure à $600000 \mathrm{UI} / \mathrm{mL}$ ) et une ÉMHO-IR supérieure à 2 s'associaient considérablement à un manque de cinétique virale et à une RVS. Cependant, l'ÉMHO-IR supérieure à 2 était la principale variable indépendante associée à un manque de RVS. Par contre, l'indice de masse corporelle, le taux d'insuline plasmatique et l'ÉMHO-IR diminuaient considérablement par rapport aux taux de départ chez les patients qui parvenaient à une RVS. Ce phénomène laisse croire à une relation de cause à effet entre l'infection par le VHC et l'IR.

CONCLUSION : L'IR chez les patients atteints du VHC chronique s'associe à une fibrose évolutive et à une cinétique virale lente. Elle pourrait prédire une absence de réponse virologique rapide et précoce. Par conséquent, il faudrait mesurer les taux de l'ÉMHO-IR et les améliorer avant d'amorcer l'antivirothérapie.

infection has been reported (5), and is associated with a greater risk for the development of hepatocellular carcinoma (HCC), providing additional evidence that DM plays an important role in the progression of liver disease and development of complications in this population (6).

Glucose abnormalities and alteration of beta-cell function have an important role in the development of IR (7), although the specific mechanisms involved in the pathogenesis of IR associated with HCV infection remain to be elucidated (8). High levels of proinflammatory and contribute to fibrotic progression in chronic HCV infection $(3,4)$

${ }^{1}$ Department of Tropical Medicine; ${ }^{2}$ Department of Internal Medicine; ${ }^{3}$ Department of Microbiology, Faculty of Medicine, Tanta University, Tanta, Egypt Correspondence: Dr Dina Ziada, Department of Hepatology and Gastroenterology, Tanta Univeristy Hospitals, Al-Geesh Street, Tanta 040, Egypt.

Telephone 011-710-9990,e-mail dhz646@hotmail.com

Received for publication April 3, 2011. Accepted September 8, 2011 
cytokines (9) and impairment of insulin receptor substrate-1 (IRS-1) and IRS-2 expression have been observed in patients with chronic hepatitis C. Moreover, HCV mediates dysfunction in the insulin signalling pathways by upregulating the expression of suppressors of cytokine signalling 3 expression (10) and increased tumour necrosis factor-alpha secretion (8). In addition to interleukin (IL)-6 and free fatty acids, cellular stress can induce IR by activating serine phosphorylation of IRS-1, thereby inhibiting its function (11).

Combination therapy with peginterferon-alpha (PEG-IFN- $\alpha 2 \mathrm{2a}$ )/ ribavirin has been recommended as standard therapy for patients with HCV infection and has shown favourable efficacy $(12,13)$. Although it is known that some pretreatment variables, such as age, viral load, level of fibrosis and IR, affect sustained virological response (SVR) in HCV-infected patients, little information is available concerning which factors interfere with the early phase of viral dynamics in these patients (14). The aim of the present study was to assess IR as a predictor of the severity of hepatic fibrosis in Egyptian HCV patients, as well as its effect on early viral kinetics and early virological response (EVR) to HCV therapy.

\section{Patients}

\section{METHODS}

Ethics approval from the Tanta University Ethics Committee and the Faculty of Medicine (Tanta, Egypt) was obtained before commencement of the present study and written informed consent was obtained from the study participants.

Patients included in the present study were nonobese (body mass index $[\mathrm{BMI}]<30 \mathrm{~kg} / \mathrm{m}^{2}$ ) chronic hepatitis C patients 18 to 60 years of age with no evidence of renal function impairment, anemia or significant reduction of their neutrophil or platelet blood counts $\left(>2 \times 10^{9} / \mathrm{L}\right.$ to $10.8 \times 10^{9} / \mathrm{L}$, and $100 \times 10^{9} / \mathrm{L}$, respectively), and fasting blood glucose level $>6.7 \mathrm{mmol} / \mathrm{L}$. Chronic hepatitis $\mathrm{C}$ was diagnosed by positivity for anti-HCV (third-generation enzyme immunoassay), HCV-RNA levels $>1000 \mathrm{IU} / \mathrm{mL}$, a liver biopsy showing chronic hepatitis and/or increased serum alanine aminotransferase (ALT) levels.

Patients were excluded if they had decompensated liver disease, hepatitis B virus infection, HIV infection, autoimmune disorders, clinically significant cardiac or cardiovascular abnormalities, clinically significant bleeding disorders, evidence of malignant neoplastic diseases, concomitant immunosuppressive medication, significant retinal disease or active seizures, a fasting blood glucose level $>120 \mathrm{mg} / \mathrm{L}$ or antidiabetic treatment, or any alcohol intake or drug abuse within six months before study entry.

\section{Clinical and laboratory examination}

Age, sex and BMI $\left(\mathrm{kg} / \mathrm{m}^{2}\right)$ were recorded for all patients at baseline. Measurements of serum levels of ALT, aspartate aminotransferase, serum bilirubin and albumin, alpha-fetoprotein, thyroid stimulating hormone, antinuclear antibody, serum creatinine and complete blood count were performed. Serum hepatitis B surface antigen and thirdgeneration HCV antibody (anti-HCV) were detected using a commercially available, third-generation ELISA kit (AxSYM 3.0, Abbott Laboratories, USA).

An overnight (12 h) fasting blood sample was drawn for measurement of fasting plasma glucose and radioimmunoassay determination of fasting serum insulin levels (Diagnostic Products Co, USA). Insulin sensitivity was determined by the homeostasis model assessment (HOMA) method (15) using the following equation:

\section{HOMA-IR=(fasting glucose $[\mathrm{mg} / \mathrm{dL}] \times$ fasting insulin $[\mathrm{IU} / \mathrm{mL}]) / 405$ \\ ( $>2$ indicating a high index of IR [16]).}

Detection/quantification of serum HCV RNA and viral kinetics Serum HCV-RNA levels were quantified in all patients at the beginning of treatment and then at weeks 4, 12, 24, 48 and 72 using a quantitative reverse-transcription polymerase chain reaction (RT-PCR) assay. Detection of serum HCV RNA was performed using a standardized automated qualitative RT-PCR assay (COBAS AMPLICOR Hepatitis C Virus Test, version 2.0; Roche, USA). The detection limit was $50 \mathrm{IU} / \mathrm{mL}$ (17). Pretreatment HCV RNA levels were determined using a branched DNA assay (Quantiplex HCV RNA 3.0, Bayer, USA) in strict accordance with the manufacturer's instructions. Because the majority of $\mathrm{HCV}$ patients in Egypt are infected with HCV genotype 4, genotyping was not performed in the present study (18).

SVR was defined as undetectable serum HCV RNA levels at week 72 (ie, 24 weeks after the end of treatment, which was also the end of follow-up). The definition of on-treatment response was as follows: rapid virological response (RVR) was defined as undetectable $\mathrm{HCV}$ RNA at week 4; complete EVR (cEVR) was defined as undetectable HCV RNA at week 12; 'non-RVR'-cEVR was defined as positive HCV RNA at week 4 but undetectable at week 12; and 'partial' EVR (pEVR) was defined as positive for HCV RNA at weeks 4 and 12 but with $\geq 2 \log _{10}$ drop in viral load at week 12 compared with baseline. Patients whose viral load declined more slowly $\left(<2 \log _{10}\right.$ drop at week 12 compared with baseline), those whose viral load dropped $>2 \log _{10}$ at week 12 compared with baseline and who were still positive for HCV RNA at week 24, those who became HCV-RNA positive after negativization before the end of treatment (breakthrough response), as well as those who became HCV-RNA positive after negativization at the end of treatment were all considered to be non-SVR subjects (19). Abdominal ultrasonography examination was performed for all study participants.

\section{Liver biopsy}

All patients underwent ultrasound-guided liver biopsy before treatment. The biopsies were examined after paraffin-embedded sections of specimens were stained with hematoxylin and eosin. Liver biopsy specimens not $<15 \mathrm{~mm}$ in length or the with presence of at least 10 complete portal tracts were required. Necroinflammatory activity was graded and fibrosis was staged according to the histological activity index (20).

\section{Study design}

The current observational case control study was started with 180 nondiabetic patients with chronic HCV who had not previously been treated with interferon alpha and/or ribavirin from Kafr El-Sheikh Liver Institute, Domiate Fever Hospital \& Tanta Fever Hospital during the period between August 2008 and June 2010. Only 140 patients continued in the study, while the other 40 patients dropped out of the study in addition to those who showed a $<2 \log _{10}$ drop in viral load at week 12 compared with baseline or those whose HCV RNA level was positive at week 24 discontinued treatment on the basis of international guidelines. According to the HOMA-IR, 140 chronic HCV patients were divided into two groups: group 1 consisted of 48 chronic HCV patients with IR (HOMA-IR $\geq 2$ ), group 2 consisted of 92 chronic HCV patients without IR (HOMA-IR <2). All patients were treated with combination PEG-IFN-2 $\alpha 180 \mu \mathrm{g} /$ week (Pegasys, Roche, Switzerland) plus oral ribavirin $1000 \mathrm{mg} /$ day combination therapy for those weighing $\leq 75 \mathrm{~kg}$ and $1200 \mathrm{mg} /$ day for those weighing $>75 \mathrm{~kg}$ for 48 weeks. Patients were evaluated at monthly intervals to monitor compliance and side effects (ie, blood cell count, serum creatinine and liver function tests).

All 140 patients who experienced $a \geq 2 \log _{10}$ decline in viral load at week 12 compared with baseline and whose HCV-RNA level was negative at week 24 continued the treatment schedule for a total of 48 weeks.

\section{Statistical analysis}

Database management and statistical analyses were performed using SPSS version 12 (IBM Corporation, USA). The $t$ test, $\chi^{2}$ and comparison proportion tests were used to compare the two groups. To predict the presence or absence of a dependent variable based on a set of predictor variables (independent variables), linear multiple logistic regression analyses were performed. Statistical significance was set at $\mathrm{P}<0.05$ for interpretation of results and tests of significance. 
TABLE 1

Demographic, virological and histopathological features of chronic hepatitis $\mathrm{C}(\mathrm{HCV})$ patients with or without insulin resistance (IR)

\begin{tabular}{lccl}
\hline & $\begin{array}{c}\text { IR chronic HCV } \\
\text { Group 1 }(\mathbf{n}=\mathbf{4 8})\end{array}$ & $\begin{array}{c}\text { Non-IR HCV } \\
\text { Group 2 }(\mathbf{n}=\mathbf{9 2})\end{array}$ & $\mathbf{P}$ \\
\hline Age, years & $42 \pm 3.1$ & $32.333 \pm 6.658$ & 0.084 \\
Male sex, n/n (\%) & $21 / 48(43.75)$ & $54 / 92(58.69)$ & $0.039^{*}$ \\
$\mathrm{BMI}, \mathrm{kg} / \mathrm{m}^{2}$ & $27.889 \pm 1.571$ & $21.01 \pm 2.646$ & $0.001^{*}$ \\
$\mathrm{ALT}, \mathrm{IU} / \mathrm{L}$ & $167 \pm 106.864$ & $99.80 \pm 64.794$ & 0.264 \\
$\mathrm{AST}, \mathrm{IU} / \mathrm{L}$ & $146.800 \pm 75.191$ & $130.000 \pm 97.747$ & 0.768 \\
Fasting glucose, mmol/L & $5.20 \pm 0.39$ & $5.22 \pm 0.29$ & 0.866 \\
Fasting insulin, pmol/L & $105.6 \pm 1.15$ & $43.2 \pm 11.4$ & $0.001^{*}$ \\
Viral load, $\log _{10}$ copies/mL & $6.34 \pm 0.54$ & $5.50 \pm 0.90$ & 0.022 * \\
Grade of inflammation $\geq 3$, & $16 / 48(33.33)$ & $23 / 92(25.1)$ & 0.415 \\
$\quad$ n/n $(\%)$ & & & \\
Fibrosis $\mathrm{F} \geq 3, \mathrm{n} / \mathrm{n}(\%)$ & $23 / 48(47.91)$ & $22 / 92(23.91)$ & $0.007^{*}$ \\
Steatosis $>5 \%, \mathrm{n} / \mathrm{n}(\%)$ & $35 / 48(72.9)$ & $27 / 92(29.34)$ & $0.0001^{*}$ \\
\hline
\end{tabular}

Data presented as mean $\pm S D$ unless otherwise indicated. *Statistically significant $(P<0.05)$. ALT Alanine aminotransferase; AST Asparatate aminotransferase; BMI Body mass index

\section{RESULTS}

Baseline characteristics of the patients are summarized in Table 1. There was no significant difference in age, levels of serum aminotransferase levels and fasting plasma glucose between IR HCV pateints (group 1) and non-IR HCV patients (group 2). However, female sex, high BMI, increased fasting insulin level, higher viral load, steatosis $>5 \%$ and advanced fibrosis $(\mathrm{F} \geq 3)$ were statistically significant in group 1 compared with group 2.

The association between IR and progressive fibrosis was evaluated by using univariate logistic regression analysis to detect factors associated with progressive fibrosis before starting treatment. Older age at the time of biopsy $(\mathrm{P}=0.007)$, higher BMI $(\mathrm{P}>0.001)$ and HOMA-IR $\geq 2$ $(\mathrm{P}<0.001)$ were factors that were significantly associated with advanced fibrosis (Table 2). On multivariate logistic regression analysis, HOMA-IR $\geq 2 \quad(P=0.040)$ remained independently associated with progressive fibrosis (Table 2 ). The influence of HOMA-IR $\geq 2$ on early viral dynamics was assessed by detecting RVR, non-RVR-cEVR, cEVR, pEVR and SVR in both groups. In the present study, group 1 patients showed significantly lower RVR (18.36\%), cEVR $(32.65 \%)$ and SVR $(26.53 \%)$ compared with group 2 patients who had RVR (31.52\%) cEVR (54.34\%) and SVR (63.04\%) (P=0.046, 0.002 and 0.001 , respectively), while, non RVR-cEVR and pEVR were insignificantly lower in group 1 compared with group 2 (Table 3 ). Viral kinetics throughout the treatment period are shown in Figure 1.

To understand the pretreatment variables influencing SVR, both univariate and multivariate logistic regression analyses were performed. Univariate analysis showed that older age, fibrosis $(\mathrm{F} \geq 3)$, high viral load ( $>600,000 \mathrm{IU} / \mathrm{mL}$ ) as well as HOMA-IR $\geq 2$ were significantly associated with a lack of SVR. However, multivariate logistic regression analysis revealed that HOMA-IR $\geq 2$ was the main independent pretreatment
TABLE 3

Early viral kinetics among chronic hepatitis C patients with and without insulin resistance

\begin{tabular}{lccc}
\hline & Group 1 $(\mathbf{n}=\mathbf{4 8})$ & Group 2 $(\mathbf{n}=92)$ & $\mathbf{P}$ \\
\hline RVR & $9(18.36)$ & $29(31.52)$ & $0.046^{*}$ \\
Non-RVR-cEVR & $7(14.28)$ & $21(22.82)$ & 0.151 \\
cEVR & $16(32.653)$ & $50(54.43)$ & $0.002^{*}$ \\
pEVR & $9(18.36)$ & $26(28.26)$ & 0.275 \\
SVR & $13(26.53)$ & $58(63.04)$ & $0.001^{*}$ \\
Non-SVR & $35(72.91)$ & $34(36.95)$ & $0.001^{*}$ \\
\hline
\end{tabular}

Data presented as $n$ (\%) unless otherwise indicated. *Statististically significant $(P<0.05)$. cEVR Complete early virological response; $p E V R$ Partial early virological response; RVR Rapid virological response; SVR Sustained virological response

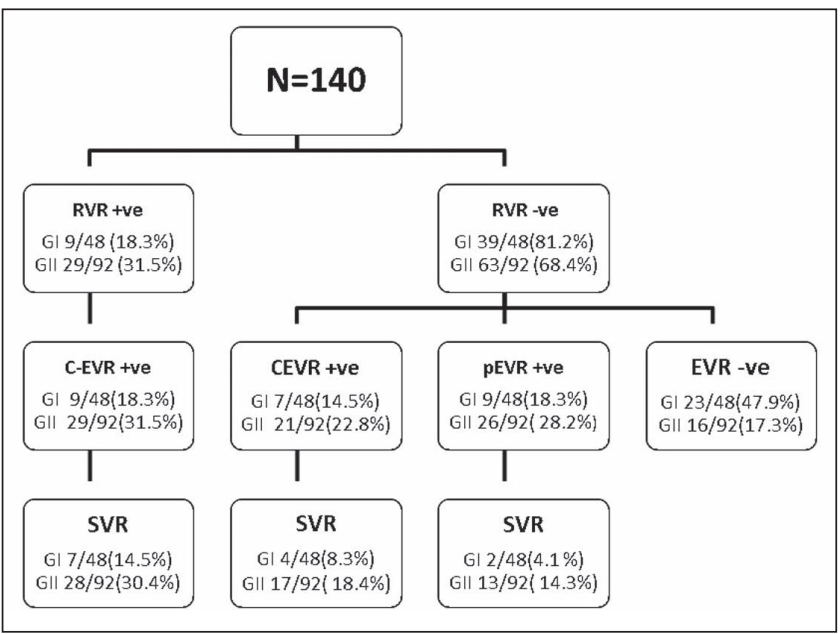

Figure 1) Viral kinetics throughout the treatment period. +ve Positive; -ve Negative; cEVR Complete early virological response; G Group; pEVR Partial early virologiacal response; RVR Rapid virological response; SVR Sustained virological response

variable statistically associated with a lack of SVR, whereas fibrosis showed a weaker association, as shown in Table 4.

BMI, fasting glucose and fasting insulin levels, and HOMA-IR were measured before starting the treatment and again at week 48 . A significant decrease among the SVR patients was revealed in BMI, insulin level and HOMA-IR (Table 5).

\section{DISCUSSION}

Chronic HCV infection is associated with a greater risk for the development of IR, and greater IR is more prevalent among patients with HCV infection compared with those with other liver diseases and with the general population (21). On the other hand, HCV patients with IR experience faster progression of hepatic fibrosis (3), extrahepatic manifestations (22) and development of HCC (23), suggesting that IR plays a crucial role in HCV infection.

\section{TABLE 2}

Pretreatment variables associated with progressive fibrosis among chronic hepatitis C patients

\begin{tabular}{|c|c|c|c|c|c|}
\hline & \multicolumn{2}{|c|}{ Univariate analysis } & \multirow[b]{2}{*}{$\mathbf{P}$} & \multicolumn{2}{|c|}{ Multivariate analysis } \\
\hline & Fibrosis F $\leq 1(n=68)$ & Fibrosis $F \geq 3(n=45)$ & & OR $(95 \% \mathrm{Cl})$ & $\mathbf{P}$ \\
\hline Age, years, mean $\pm S D$ & $31.333 \pm 2.082$ & $47.667 \pm 5.13$ & $0.007^{*}$ & $0.99(0.74-1.33)$ & 0.258 \\
\hline Male sex & $36(52.9)$ & $21(46.6)$ & 0.643 & - & - \\
\hline Body mass index, $\mathrm{kg} / \mathrm{m}^{2}$, mean $\pm \mathrm{SD}$ & $21.80 \pm 03.701$ & $28.200 \pm 1.789$ & $0.001^{*}$ & $0.82(0.63-1.08)$ & 0.174 \\
\hline High viral load ${ }^{\dagger}$ & $34(50)$ & $19(42.2)$ & 0.535 & - & - \\
\hline HOMA-IR $\geq 2$ & $14(20.58)$ & $26(57.78)$ & $0.001^{*}$ & $1.92(0.97-3.40)$ & $0.049^{\star}$ \\
\hline Grade of inflammation $\geq 3$ & $32(47.05)$ & $21(42.9)$ & 0.810 & - & - \\
\hline Steatosis $>5 \%$ & $22(32.35)$ & $23(51.1)$ & 0.077 & & \\
\hline
\end{tabular}

Data presented as $n$ (\%) unless otherwise indicated. *Statistically significant; ${ }^{\dagger}>600,000$ IU/mL. HOMA-IR Homeostasis model assessment-insulin resistance 
Table 4

Factors associated with lack of sustained virological response (SVR) determined by univariate and multivariate logistic regression analysis

\begin{tabular}{|c|c|c|c|c|c|}
\hline & \multicolumn{3}{|c|}{ Univariate analysis } & \multicolumn{2}{|c|}{ Multivariate analysis } \\
\hline & SVR $(n=71)$ & Non-SVR $(n=69)$ & $\mathbf{P}$ & OR $(95 \% \mathrm{Cl})$ & $\mathbf{P}$ \\
\hline Age, years, mean $\pm S D$ & $32.20 \pm 10.474$ & $49.400 \pm 7.925$ & $0.019 *$ & $0.94(0.97-1.16)$ & 0.605 \\
\hline Male sex & $43(61.97)$ & $31(44.9)$ & 0.052 & & \\
\hline Body mass index, $\mathrm{kg} / \mathrm{m}^{2}$, mean $\pm \mathrm{SD}$ & $24.34 \pm 3.782$ & $26.100 \pm 3.36$ & $0.007^{\star}$ & $1.93(0.63-2.31)$ & 0.096 \\
\hline High viral $\operatorname{load}^{\dagger}$ & $28(39.4)$ & $40(57.97)$ & $0.042^{*}$ & $1.17(0.82-1.65)$ & 0.379 \\
\hline HOMA-IR $\geq 2$ & $13(18.30)$ & $35(50.72)$ & $<0.001^{\star}$ & $2.44(1.11-5.47)$ & $0.003^{*}$ \\
\hline Grade of inflammation $\geq 3$ & $27(38.02)$ & $34(49.27)$ & 0.241 & & \\
\hline Advanced fibrosis $(F \geq 3)$ & $14(19.710)$ & 31 (44.93) & $0.003^{*}$ & $2.01(0.75-3.31)$ & $0.030 *$ \\
\hline Steatosis $>5 \%$ & $28(39.34)$ & $39(56.52)$ & 0.241 & & \\
\hline
\end{tabular}

Data presented as $n$ (\%) unless otherwise indicated. * Statistically significant; ${ }^{\dagger}>600,000 \mathrm{IU} / \mathrm{mL}$. HOMA-IR Homeostasis model assessment-insulin resistance

TABLE 5

Metabolic and biochemical evaluation during treatment in patients who achieved sustained virological response

\begin{tabular}{lccl}
\hline & Baseline & Week 48 & P \\
\hline Body mass index, $\mathrm{kg} / \mathrm{m}^{2}$ & $28.0 \pm 1.581$ & $22.20 \pm 2.387$ & $0.002^{*}$ \\
Fasting glucose, $\mathrm{mmol} / \mathrm{L}$ & $5.236 \pm 0.223$ & $5.194 \pm 0.295$ & 0.104 \\
Fasting insulin, $\mathrm{pmol} / \mathrm{L}$ & $65.67 \pm 18.64$ & $49.9 \pm 8.34$ & $0.038^{*}$ \\
HOMA-IR & $2.280 \pm 0.540$ & $1.660 \pm 0.207$ & $0.009^{*}$ \\
\hline
\end{tabular}

Data presented as mean \pm SD. *Statistically significant. HOMA-IR Homeostasis model assessment - insulin resistance

In the present study, HCV patients with IR were characterized by a preponderance of women, higher BMI, insulin levels, viral load, steatosis $>5 \%$ and fibrosis $(\mathrm{F} \geq 3)$ compared with $\mathrm{HCV}$ patients without IR. A significant increase in steatosis and fibrosis confirms the association between fatty liver (nonalcoholic fatty liver disease/nonalcoholic steatohepatitis) and chronic HCV-infected patients with IR. Whether IR could be the cause or consequence of steatosis and fibrosis is unknown. Fartoux et al (24) found that IR in patients infected with HCV genotype 1 is the cause rather than the consequence of hepatic steatosis and fibrosis, and suggests that increased circulating insulin is a risk factor for fibrosis through IR-induced steatosis.

Our study found that older age, higher BMI and HOMA-IR $\geq 2$ were associated factors with progressive fibrosis, and that HOMA-IR $\geq 2$ remained independently associated with progressive fibrosis. These results are in agreement with Cua et al (25), who studied 346 nondiabetic patients with HCV and concluded that IR is a major independent determinant of fibrosis in chronic HCV infection, regardless of the genotype and the severity of liver damage. The results are also in agreement with those of Halfon et al (26), who studied the influence of IR on hepatic fibrosis and steatosis in HCV-infected patients and found that liver fibrosis is significantly associated with IR independent of liver steatosis only among HCV-monoinfected patients. In fact, it has been demonstrated that high levels of insulin and glucose could promote fibrogenesis by stimulating the release of connective tissue growth factor - a fibrogenic growth factor - from hepatic stellate cells (27).

The relationship between IR and fibrosis has been clarified by Fartoux et al (24), who found a significant link between circulating insulin levels and fibrosis stage using univariate analysis, while multivariate analysis revealed that steatosis, but not insulin, was independently associated with fibrosis, suggesting an indirect effect of the circulating insulin level on fibrosis stage through a steatosisrelated pathway. This relationship between steatosis and fibrosis could be explained by several mechanisms, such as lipid peroxidation (28-32), and the 'two hits hypothesis', in which steatosis could increase the sensitivity of hepatocytes to oxidative stress, the second hit being $\mathrm{HCV}$ infection itself in patients with chronic HCV (28) .

The present study evaluated the impact of pretreatment IR on SVR. We found that older age, fibrosis $(\mathrm{F} \geq 3)$, high viral load $(>600,000 \mathrm{IU} / \mathrm{mL})$ as well as HOMA-IR $\geq 2$ were significantly associated with a lack of SVR. HOMA-IR $\geq 2$ was found to be the main independent variable associated with lack of SVR. Our study reveals an insignificant association between steatosis and lack of SVR indicating that fatty liver (nonalcoholic fatty liver disease/nonalcoholic steatohepatitis) can lead to a lack of SVR indirectly through progressive fibrosis or IR.

These results are supported by the results reported by RomeroGomez et al (13), who in a prospective study of Spanish patients with chronic hepatitis C found an SVR rate of only $32.8 \%$ in HCV genotype 1 patients with IR compared with an SVR rate of $60.5 \%$ in those without IR, and concluded that IR impairs the response to therapy in patients infected with chronic HCV. Furthermore, Poustchi et al (28) found that patients with HOMA-IR $<2$ were 6.5 times more likely to achieve SVR than those with HOMA-IR $\geq 2$.

Our results differ from those of Merchante et al (33), who studied the impact of IR on SVR of HIV/HCV coinfection; they found that IR is not a relevant predictor of SVR to PEG-IFN plus ribavirin in HIV/ HCV-coinfected patients. This can be explained by the different scenarios of hepatic fibrosis and steatosis in HCV monoinfection and HIV/ HCV coinfection, which is supported by Halfon et al (26), who found that while IR is associated with significant liver fibrosis in HCV monoinfected patients this does not happen with HIV/HCV coinfected patients.

To understand whether the impact of IR on SVR occurs as a result of its effect on early viral kinetics, our study assessed the influence of IR on early viral kinetics by detecting RVR, non RVR-cEVR, cEVR, pEVR and SVR in IR and non-IR HCV patients. We found that RVR and cEVR were significantly lower in insulin-resistant HCV patients compared with non-insulin-resistant HCV patients, while non-RVR-cEVR and pEVR were lower in IR HCV compared with non-IR HCV patients, but did not reach statistical significance. The significant lack of SVR among the IR group compared with non-IR HCV patients was consequently attributed to slow viral kinetics with lack of RVR and EVR. These results are supported by those of Napoli et al (34), who found that RVR at week 4 of treatment was strongly associated with the likelihood of achieving SVR in genotype $1 \mathrm{HCV}$ patients, regardless of the therapeutic regimen, and patients who did not clear the virus within the first 12 weeks of treatment had little chance of achieving SVR. In addition, Yu et al (35) studied the predictive value of RVR and EVR on SVR in HCV genotype 1 patients and found that genotype, RVR and EVR were independent factors for predicting the effect of antiviral therapy. Therefore, the pretreatment HOMA-IR could not only predict treatment outcome but could also predict RVR and EVR. These results go hand in hand with those of Grasso et al (36), who concluded that IR could predict RVR in nondiabetic, noncirrhotic genotype $1 \mathrm{HCV}$ patients (36). According to these results, this study suggests that the improvement in IR either by weight loss, lifestyle change or insulin sensitizer will lead to rapid viral kinetics, improving the RVR and EVR, which will, therefore, improve SVR in chronic HCV patients. This is supported by Khattab et al (37), who found that pioglitazone improves virological response 
to PEG-IFN-2 $\alpha$ /ribavirin combination therapy in hepatitis $\mathrm{C}$ genotype 4 patients with IR.

On the other hand, our study demonstrates that HOMA-IR, BMI and insulin levels showed significant decreases at 48 weeks in SVR patients compared with their starting levels. This improvement happened without exercise, dietary or lifestyle changes, or insulin sensitizer intake. This suggests a cause-effect relationship between HCV and IR, which warrants further study.

\section{CONCLUSION}

IR in chronic HCV patients is associated with advanced fibrosis, slow viral kinetics and could be a predictor for lack of RVR and EVR. Therefore, HOMA-IR levels should be assessed and improved before initiating antiviral treatment in chronic HCV patients.

ACKNOWLEDGEMENT: The authors thank Dr Abd El Moneim El Hadydy from Domiate Fever hospital for his great effort in supporting the work during this study.

DISCLOSURES: The authors have no financial disclosures or conflicts of interest to declare.

\section{REFERENCES}

1. Flamm SL. Chronic hepatitis $C$ virus infection. JAMA 2003;289:2413-7.

2. Mazzaro C, Panarello G, Tesio F, et al. Hepatitis C virus risk: A hepatitis C virus-related syndrome. J Intern Med 2000;247:535-45.

3. Hui JM, Sud A, Farrell GC, et al. Insulin resistance is associated with chronic hepatitis $\mathrm{C}$ virus infection and fibrosis progression. Gastroenterology 2003;125:1695-704.

4. Svegliati-Baroni G, Bugianesi E, et al. Post-load insulin resistance is an independent predictor of hepatic fibrosis in virus $\mathrm{C}$ chronic hepatitis and in nonalcoholic fatty liver disease. Gut 2007;56:1296-301.

5. Dai CY, Chuang WL, Ho CK, et al. Associations between hepatitis $\mathrm{C}$ viremia and low serum triglyceride and cholesterol levels: A community-based study. J Hepatol 2008;49:9-16.

6. Taura N, Ichikawa T, Hamasaki K, et al. Association between liver fibrosis and insulin sensitivity in chronic hepatitis $\mathrm{C}$ patients. Am J Gastroenterol 2006;101:2752-9.

7. Petit JM, Bour JB, Galland-Jos C, et al. Risk factors for diabetes mellitus and early insulin resistance in chronic hepatitis C. J Hepatol 2001;35:279-83.

8. Shintani Y, Fujie H, Miyoshi H, et al. Hepatitis C virus infection and diabetes: Direct involvement of the virus in the development of insulin resistance. Gastroenterology 2004;126:840-8.

9. Masini M, Campani D, Boggi U, et al. Hepatitis $\mathrm{C}$ virus infection and human pancreatic $\beta$-cell dysfunction. Diabetes Care 2005;28:940-1.

10. Kawaguchi T, Yoshida T, Harada M, et al. Hepatitis C virus down-regulates insulin receptor substrates 1 and 2 through upregulation of suppressor of cytokine signaling 3. Am J Pathol 2004;165:1499-508.

11. Aguirre V, Werner ED, Giraud J, Lee YH, Shoelson SE, White MF. Phosphorylation of Ser307 in insulin receptor substrate-1 blocks interactions with the insulin receptor and inhibits insulin action. J Biol Chem 2002;277:1531-7.

12. Strader DB, Wright T, Thomas DL, Seeff LB. American Association for the Study of Liver Diseases. Diagnosis, management, and treatment of hepatitis C. Hepatology 2004;39:1147-71.

13. Romero-Gomez M, Del MV, Andrade RJ, et al. Insulin resistance impairs sustained response rate to peginterferon plus ribavirin in chronic hepatitis C patients. Gastroenterology 2005;128:636-41

14. Grasso A, Malfatti F, De Leo P, et al. Insulin resistance predicts rapid virological response in non-diabetic, non-cirrhotic genotype 1 $\mathrm{HCV}$ patients treated with peginterferon alpha-2b plus ribavirin. J Hepatol 2009;51:984-90.

15. Narita R, Abe S, Kihara Y, Akiyama T, Tabarau A, Otsuki M. Insulin resistance and insulin secretion in chronic hepatitis $\mathrm{C}$ virus infection. J Hepatol 2004;41:132-8.
16. Knobler H, Zhornicky T, Sandler A, Haran N, Ashur Y, Schattner A. Tumor necrosis factor- $\alpha$-induced insulin resistance may mediate the hepatitis $\mathrm{C}$ virus-diabetes association. Am J Gastroenterol 2003;98:2751-6

17. Conjeevaram HS, Kleiner DE, Everhart JE, et al. Race, insulin resistance and hepatic steatosis in chronic hepatitis C. Hepatology 2007;45:80-7.

18. Sievert W, Altraif I, Razavi HA, et al. A systematic review of hepatitis $\mathrm{C}$ virus epidemiology in Asia, Australia and Egypt. Liver Int 2011;31(Suppl 2):61-80.

19. Hadziyannis SJ, Sette Jr H, Morgan TR, et al. Peginterferon-alpha2a and ribavirin combination therapy in chronic hepatitis $\mathrm{C}$ : A randomized study of treatment duration and ribavirin dose. Ann Intern Med 2004;140:346-55.

20. Ishak KG. Chronic hepatitis: Morphology and nomenclature. Mod Pathol 1994;7:690-713.

21. Mason AL, Lau JY, Hoang N, et al. Association of diabetes mellitus and chronic hepatitis $\mathrm{C}$ virus infection. Hepatology 1999;29:328-33.

22. Sumie S, Kawaguchi T, Komuta M, et al. Significance of glucose intolerance and SHIP2 expression in hepatocellular carcinoma patients with HCV infection. Oncol Rep 2007;18:545-52.

23. El-Serag HB, Tran T, Everhart JE. Diabetes increases the risk of chronic liver disease and hepatocellular carcinoma. Gastroenterology 2004;126:460-8.

24. Fartoux L, Poujol-Robert A, Gue'chot J, Wendum D, Poupon R, Serfaty L. Insulin resistance is a cause of steatosis and fibrosis progression in chronic hepatitis C. Gut 2005;54:1003-8.

25. Cua IH, Hui JM, Kench JG, George J. Genotype-specific interactions of insulin resistance, steatosis, and fibrosis in chronic hepatitis C. Hepatology 2008;48:723-31

26. Halfon $P$, Pénaranda $G$, Carrat F. Influence of insulin resistance on hepatic fibrosis and steatosis in hepatitis $\mathrm{C}$ virus (HCV) monoinfected compared with HIV-HCV co-infected patients. Aliment Pharmacol Ther 2009;30:61-70. Epub March 9, 2009.

27. Paradis V, Perlemuter G, Bonvoust F, et al. High glucose and hyperinsulinemia stimulate connective tissue growth factor expression: A potential mechanism involved in progression to fibrosis in nonalcoholic steatohepatitis. Hepatology 2001;34:738-44.

28. Poustchi H, Negro F, Hui J, et al. Insulin resistance and response to therapy in patients infected with chronic hepatitis $\mathrm{C}$ virus genotypes 2 and 3. J Hepatol 2008;48:28-34. Epub October 1, 2007.

29. Fartoux L, Serfaty L, Lefevre G, et al. Steatosis, oxidative stress and fibrosis in chronic hepatitis C. Hepatology 2003;38:363A.

30. Day CP, James OF. Steatohepatitis: A tale of two "hits"? Gastroenterology 1998;114:842-5.

31. Lerat $\mathrm{H}$, Honda M, Beard MR, et al. Steatosis and liver cancer in transgenic mice expressing the structural and non-structural proteins of hepatitis C virus. Gastroenterology 2002;122:352-65.

32. Letteron P, Fromenty B, Terris B, et al. Acute and chronic hepatic steatosis lead to in vivo lipid peroxidation in mice. J Hepatol 1996;24:200-8.

33. Merchante N, Macías J, Palacios RB, et al. Prevalence of nonsignificant liver fibrosis and rate of fibrosis progression in HIV/ hepatitis $\mathrm{C}$ virus- co-infected patients: Still a role for liver biopsy? AIDS 2004;18:1746-8.

34. Napoli N, Giannelli G, Parisi CV, Antonaci A, Maddalena G, Antonaci S. Predictive value of early virological response to treatment with different interferon-based regimens plus ribavirin in patients with chronic hepatitis C. New Microbiol 2005;28:13-21.

35. Yu JW, Wang GQ, Sun LJ, Li XG, Li SC. Predictive value of rapid virological response and early virological response on sustained virological response in $\mathrm{HCV}$ patients treated with pegylated interferon alpha-2a and ribavirin. J Gastroenterol Hepatol 2007;22:832-6.

36. Grasso A, Malfatti F, De Leo P, et al. Insulin resistance predicts rapid virological response in non-diabetic, non-cirrhotic genotype 1 $\mathrm{HCV}$ patients treated with peginterferon alpha-2b plus ribavirin. J Hepatol 2009;51:984-90. Epub July 23, 2009.

37. Khattab M, Emad M, Abdelaleem A. Pioglitazone improves virological response to peginterferon alpha-2b/ribavirin combination therapy in hepatitis $\mathrm{C}$ genotype 4 patients with insulin resistance. Liver Int 2010;30:447-54. Epub November 16, 2009. 


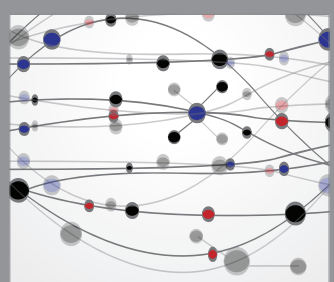

The Scientific World Journal
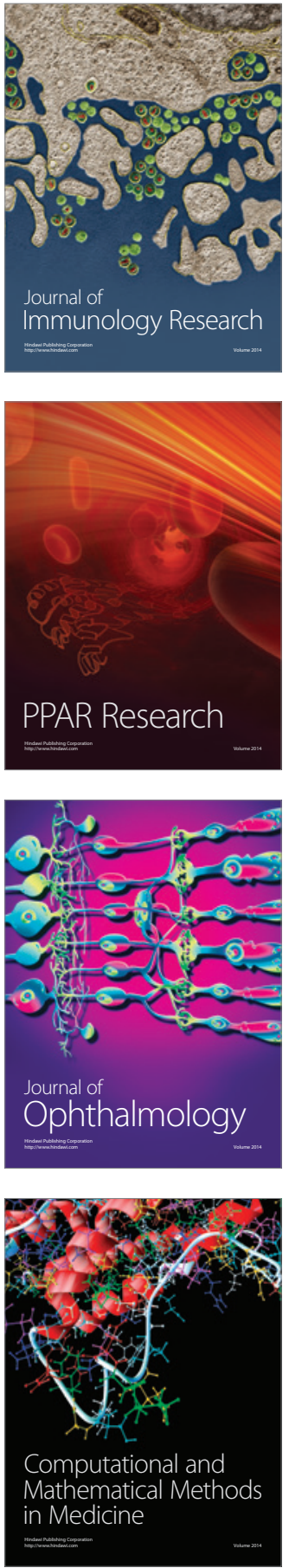

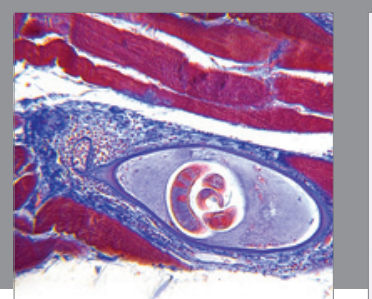

Gastroenterology Research and Practice

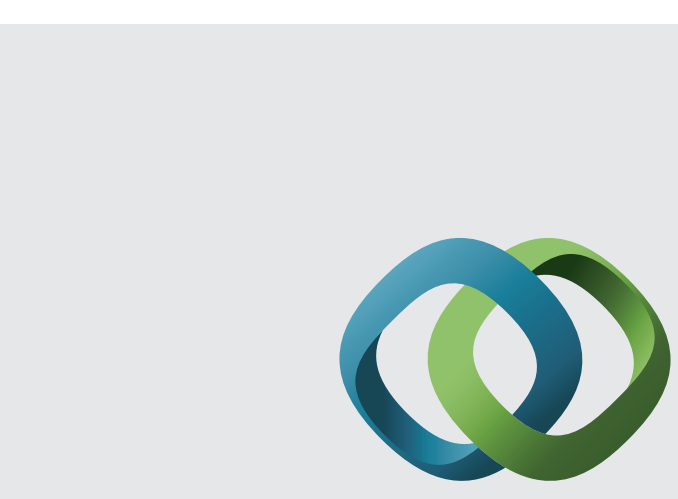

\section{Hindawi}

Submit your manuscripts at

http://www.hindawi.com
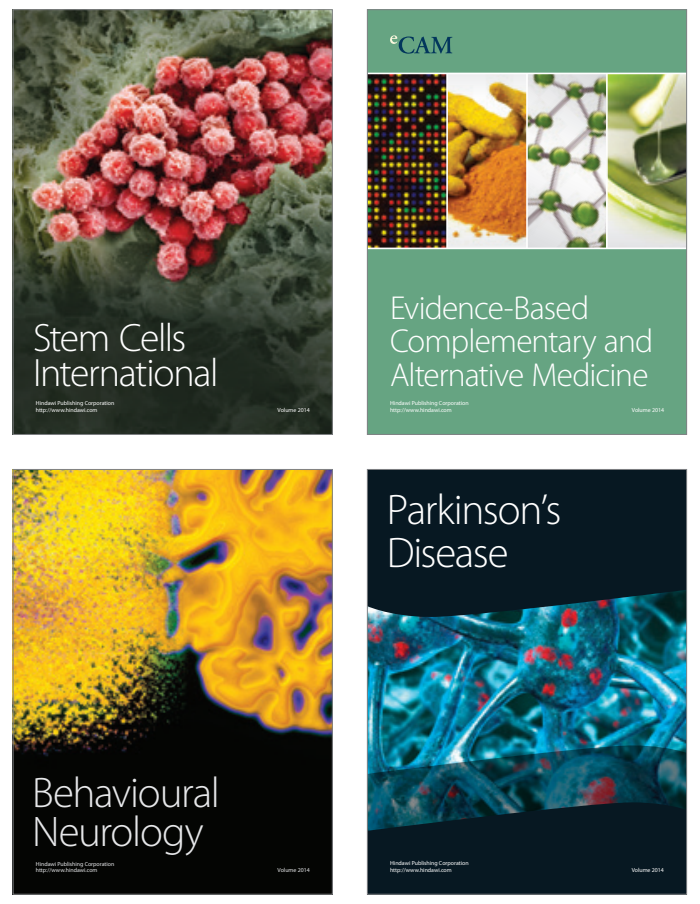
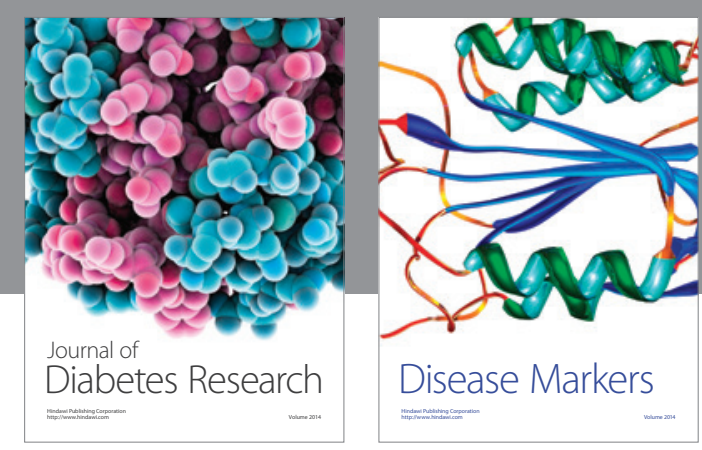

Disease Markers
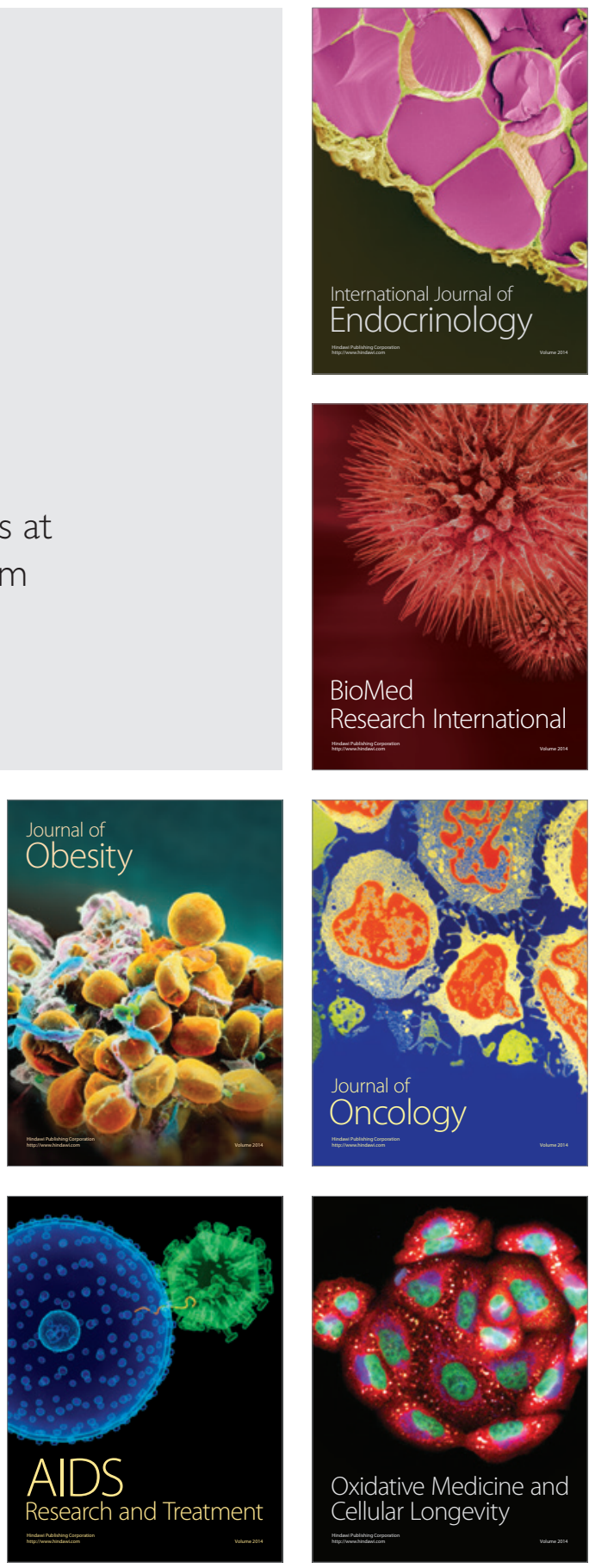